\title{
Correlation between radiation dose and p53 protein expression levels in human lymphocytes
}

\author{
MARIANA B. CAVALCANTI ${ }^{1}$, THIAGO S. FERNANDES ${ }^{1,2}$, \\ EDVANE B. SILVA ${ }^{1,3}$ and ADEMIR AMARAL ${ }^{1}$ \\ ${ }^{1}$ Laboratório de Modelagem e Biodosimetria Aplicada (LAMBDA), \\ Departamento de Energia Nuclear, Universidade Federal de Pernambuco, \\ Avenida Professor Luiz Freire, 1000, Cidade Universitária, 50740-540 Recife, PE, Brasil \\ ${ }^{2}$ Departamento de Biofísica e Radiobiologia, Universidade Federal de Pernambuco, \\ Avenida Moraes Rego, 1235, Cidade Universitária, 50670-901 Recife, PE, Brasil \\ ${ }^{3}$ Centro Acadêmico de Vitória, Universidade Federal de Pernambuco, \\ Rua Alto do Reservatório, s/n, 55608-680 Vitória de Santo Antão, PE, Brasil \\ Manuscript received on February 5, 2015; accepted for publication on April 29, 2015
}

\begin{abstract}
The aim of this research was to evaluate the relationship between p53 protein levels and absorbed doses from in vitro irradiated human lymphocytes. For this, samples of blood from 23 donors were irradiated with $0.5 ; 1 ; 2$; and 4 Gy from a Cobalt- 60 source, and the percentages of lymphocytes expressing p53 were scored using Flow Cytometry. The subjects were divided into 3 groups, in accordance with the p53 levels expressed per radiation dose: low (Group I), high (Group II), and excessive levels (Group III). For all groups, the analyses showed that the p53 expression levels increase with the absorbed dose. Particularly for groups I and II, the correlation between this protein expression and the dose follows the linear-quadratic model, such as for radioinduced chromosomal aberrations. In conclusion, our findings indicate possible applications of this approach in evaluating individual radiosensitivity prior to radiotherapeutical procedures as well as in medical surveillance of occupationally exposed workers. Furthermore, due to the rapidity of flow-cytometric analyses, the methodology here employed would play an important role in emergency responses to a large-scale radiation incident where many people may have been exposed.
\end{abstract}

Key words: Biological Dosimetry, cellular radiobiology, Flow Cytometry, p53 protein, radiosensitivity.

\section{INTRODUCTION}

Ionizing radiation (IR) is a physical agent used in many fields, such as in medicine for diagnosis and treatment of diseases, and for industrial purposes. Due to the adverse health effects of this agent, the evaluation of the risks associated to individual

Correspondence to: Mariana B.C. Freire Bezerra

E-mail: maribrayner@yahoo.com.br exposure to IR is a very important issue. This assessment can be done by measuring biomarkers, which are modifications of biological parameters induced by the interaction of this type of radiation with the living tissue (Amaral et al. 2008, LemosPinto et al. 2010).

The risk assessment through biomarkers may be a critical step in radiation surveillance for indicating 
whether individuals have been considerably exposed to IR, and, sometimes, to determine what level of absorbed dose they have been exposed to. The frequency of dicentric chromosomes in peripheral blood lymphocytes is the most widely used biomarker for estimating the individual absorbed dose. Despite being the "gold standard" in biodosimetry, the dicentric scoring-based methodology is too laborious and time consuming, which would be of great concern in cases of radiation emergencies, where quick responses are crucial for an early and better management of cases associated to acute radiation syndrome (Amaral et al. 2008, Fernandes et al. 2008). Furthermore, it is well known that not all people respond equally to the same level of exposure to IR, some of them presenting overreactions (Orient 2014).

The search for innovative biological methods of screening an irradiated population is nowadays motivated by the advent of new technologies that enable better studies of gene and protein expressions (Guipaud and Benderitte 2009). This is especially important in, for example, a mass casualty event such as the recent nuclear incident of Fukushima in Japan (Lee et al. 2012, Chen et al. 2014).

The two main radiation-induced DNA damages, single strand breaks (SSB) or double strand breaks (DSB), can be misrepaired so as to generate abnormal dicentric chromosomes (Sweigert et al. 1989, Olive 1998, Pojoga et al. 2013). When the DNA is injured, the protein $\mathrm{p} 53$, so-called the "Guardian of the Genome", is expressed. This protein acts by coordinating the response to DNA injuries in a transcription-dependent and independent manner (Riley et al. 2008, RashiElkeles et al. 2014). One of the multiple roles played by $\mathrm{p} 53$ after radiation is to act as a transcription factor by binding to specific DNA sequences and consequently inducing activation or even repression of pivotal genes enrolled in cell-cycle arrest, DNA repair and apoptosis (Speidel 2010).

From in vitro irradiated human lymphocytes, it was demonstrated elsewhere that the p53 protein expression increases with the radiation levels (Cavalcanti et al. 2008, 2011). Hence, it is evident that there is proportionality between absorbed dose and biomarkers of radiation exposures, such as the formation of dicentric chromosomes, the $\mathrm{p} 53$ protein expression, and the $\gamma \mathrm{H} 2 \mathrm{AX}$ phosphorylation, all of these as a result of DNA double strand breaks (Redon et al. 2009, Rothkamm and Horn 2009).

In order to investigate the potential of $\mathrm{p} 53$ as a candidate for biomarker of individual exposure to IR, the aim of this research was to measure the relationship between p53 protein levels and absorbed doses in human lymphocytes from in vitro irradiated peripheral blood.

\section{MATERIALS AND METHODS}

StUdiEd PopUlation AND ETHICAL ASPECTS

This research was performed with 23 healthy volunteers, being 10 females (aged 19 to 42 years) and 13 males (aged 22 to 36 years). All individuals involved in this research signed a written informed consent before blood collection, following recommendations of the ethics committee of the Fundação de Hematologia e Hemoterapia de Pernambuco (HEMOPE/Brazil) (Number 046/06).

IRRADIATION AND PROCESSING OF SAMPLES

For each donor, 50-mL samples of peripheral blood were divided into five equal aliquots. From each sample, one aliquot was kept as control (non-irradiated), and the other four aliquots were separately exposed to gamma radiation using a Cobalt-60 source (Theratron 780 - Atomic Energy of Canada Ltd), dose rate $196.67 \mathrm{cGy} / \mathrm{min}$, to deliver the following absorbed doses of $0.5 ; 1 ; 2$; and $4 \mathrm{~Gy}$. This interval of absorbed doses involves the spectrum of in vitro dose of calibration curves for estimating biological damage in cases of radiological incidents, as well as covers the dose levels with relevance to radiotherapy. 


\section{Isolation of Peripheral Blood MonONuClear CELlS}

After irradiation, blood was diluted (1:1) with phosphate-buffered saline (PBS, pH 7.2) and deposited onto the Ficoll-Paque PLUS density $(1.077 \mathrm{~g} / \mathrm{mL})$ gradient (GE Healthcare, USA). After centrifugation, peripheral blood mononuclear cells (PBMC) were individually removed, washed twice with PBS and resuspended in RPMI-1640 medium (Cultilab, Brazil) supplemented with 10\% fetal bovine serum (Cultilab, Brazil) at density of $2 \times 10^{6}$ cells $/ \mathrm{mL}$. The cell viability was evaluated using trypan blue dye $0.4 \%$ (Sigma-Aldrich, USA), in accordance to the methodology described elsewhere (Cavalcanti et al. 2011). Only samples with more than $80 \%$ of viable cells were cultured.

\section{LYMPHOCYTE CULTURE}

The methodology for cell cultures was adapted from De Freitas e Silva et al. (2014). In short: cells were plated in 96-well bottom plates (TPP, Switzerland) at density of $2 \times 10^{5}$ cells/well and cultured at a final concentration of phytohemagglutinin (PHA) of $10 \mu \mathrm{g} / \mathrm{mL}$. Plates were incubated in a humidified atmosphere of $5 \% \mathrm{CO}_{2}$ at $37^{\circ} \mathrm{C}$ for $72 \mathrm{~h}$.

Cell Labeling With ANTiBodies

All methods employed in this work for cell labeling were previously tested and established (Cavalcanti et al. 2008, 2011). After cell culture, cells were harvested and washed with RPMI-1640 medium supplemented with $10 \%$ fetal bovine serum. For permeabilization, cells were resuspended in solution containing $1 \mathrm{~mL}$ of FACS lysing solution (BD Pharmigen, USA) diluted in water $(1 / 10)$ and $9 \mathrm{~mL}$ of $4 \%$ paraformaldehyde in PBS, and incubated for $10 \mathrm{~min}$ at room temperature. After this, cells were washed with PBS $0.05 \%$ Tween 20 (Merck, Germany) at $400 \mathrm{x}$ g for $5 \mathrm{~min}$. Cell pellet was resuspended in $200 \mu \mathrm{L}$ of PBS $0.05 \%$ Tween 20 and stained with phycoerithrin (PE)conjugated anti-p53 antibody (clone G59-12) (BD Pharmigen, USA) for $20 \mathrm{~min}$ at room temperature.
PE-conjugated mouse IgG1 (clone MOPC-21) (BD Pharmigen, USA) was used as isotype control antibody. Then, cells were washed twice in PBS $0.05 \%$ Tween 20 and fixed with $500 \mu \mathrm{L}$ of $1 \%$ paraformaldehyde in PBS.

\section{FLOW CYTOMETRY}

The percentage of lymphocytes expressing p53 was scored using Flow Cytometry (FC). The analyses were performed on a FACScalibur flow cytometer (Becton Dickinson, USA), equipped with a $15 \mathrm{~mW}$ argon-ion laser (wavelength 488 $\mathrm{nm}$ ), using Cell Quest pro software (Becton Dickinson Immunocytometry Systems, USA). Based on scatter parameters, cells were graphically settled according to its size and granularity, and from this visualization, lymphocyte population was electronically selected with a gate tool (lymphogate). For each analysis, 50,000 events were scored and the p53 final levels were calculated by subtraction of isotype control (less than 1\%) from $\mathrm{p} 53$ expression value.

\section{STATISTICAL ANALYSES}

For evaluating whether the data followed a Normal distribution, the Shapiro-Wilk test was used. To compare biological response differences among absorbed doses, ANOVA and Post-hoc Tukey were applied. Lastly, the t-student test was employed to determine the interval of confidence of the percentage of $\mathrm{p} 53$ protein expression $(\mathrm{p}<0.05)$.

\section{RESULTS}

Based on the level of p53 expressed in blood samples after in vitro irradiation, the subjects were grouped as following: Group I, formed by subjects $(\mathrm{n}=8)$ presenting the lowest levels of $\mathrm{p} 53$ protein expression per dose; Group II, formed by subjects $(n=13)$ with higher expression of $\mathrm{p} 53$; Data collected from groups I and II fitted into a Normal Distribution $(p<0.05)$. Group III was by subjects $(n=2)$ with elevated levels of p53 expressions 
per dose, and were considered as outliers. In the classification of these groups, age or sex of the subjects was not considered.
Table I presents the interval of confidence of p53 protein expression level for different absorbed doses in the case of groups I and II.

TABLE I

Interval of confidence of $\mathbf{p 5 3}$ protein expression level for different absorbed doses and control (non-irradiated).

\begin{tabular}{cccccc}
\hline \multicolumn{7}{c}{ p53 EXPRESSION LEVEL (\%) } \\
\hline \multicolumn{7}{c}{ Radiation Dose (Gy) } \\
\hline GROUPS & Control & $\mathbf{0 . 5}$ & $\mathbf{1 . 0}$ & $\mathbf{2 . 0}$ & $\mathbf{4 . 0}$ \\
I & $0.08-0.44$ & $0.00-0.60$ & $0.12-0.78$ & $0.34-2.33$ & $2.94-6.11$ \\
II & $1.07-1.75$ & $1.05-3.01$ & $1.36-4.24$ & $3.84-9.67$ & $10.97-16.30$ \\
\hline
\end{tabular}

From Table I, it can be noticed that the p53 expression levels of Group I, responded less intensely (from $0.08 \%$ to $6.11 \%$ ) to the absorbed doses. When compared to the p53 expression levels shown by the Group II (1.07\% to $16.30 \%)$, the "lower responders" given by the first group, may be an indicator that those former subjects are more resistant in terms of radiation-induced cell death.

Figure 1 presents the means of $\mathrm{p} 53$ expression levels in lymphocytes after in vitro irradiation with absorbed doses of $0.5 ; 1 ; 2$; and 4 Gy, including the background (non-irradiated sample), from 72-hour cell cultures in the presence of phytohaemaglutinin (PHA) in the beginning of cell culture in order to induce mitosis.

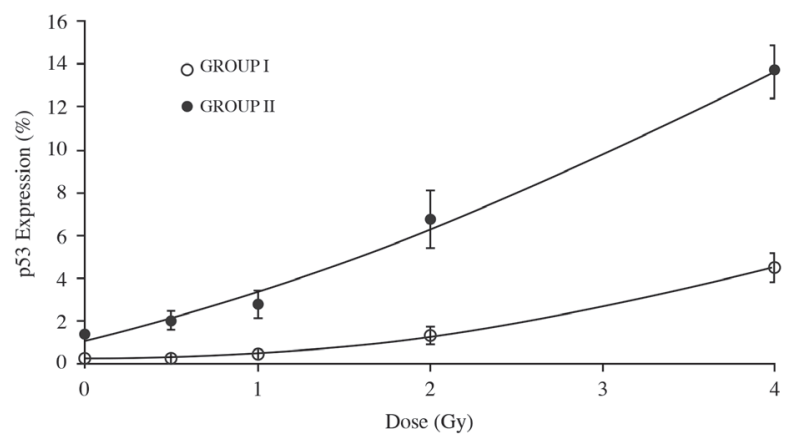

Figure 1 - Mean percentage of the p53 protein expression levels in non-irradiated ( 0 Gy) and irradiated $(0.5 ; 1 ; 2 ; 4$ Gy) lymphocytes for Groups I and II.

Table II shows the p53 protein expression level from samples of the two subjects considered as outliers in terms of pattern in response to ionizing radiation. Those donors, coded as $\mathbf{S 1}$ and $\mathbf{S 2}$, form Group III and their cells expressed much higher p53 protein expression levels than the ones of the other studied individuals, with a different tendency as the dose increased. For these two subjects, statistically significant differences among control and absorbed doses of $0.5 ; 1 ; 2$; and 4 Gy $(p<0.05)$, was observed.

TABLE II

p53 protein expression levels in lymphocytes from subjects S1 and S2, for non-irradiated (Control) and irradiated $(0.5 ; 1 ; 2 ; 4$ Gy) samples.

\begin{tabular}{cccccc}
\hline \multicolumn{6}{c}{ p53 EXPRESSION LEVEL (\%) } \\
\hline \multicolumn{5}{c}{ Radiation Dose (Gy) } \\
\hline Samples & Control & $\mathbf{0 . 5}$ & $\mathbf{1 . 0}$ & $\mathbf{2 . 0}$ & $\mathbf{4 . 0}$ \\
S1 & 1.00 & 48.57 & 37.72 & 40.95 & 52.18 \\
S2 & 0.41 & 4.56 & 48.49 & 22.73 & 60.87 \\
\hline
\end{tabular}

\section{DISCUSSION}

The discovery of new, quicker biomarkers of individual exposure to ionizing radiation would be of great significance for a faster identification of highly exposed people, complementary to other conventional investigated biological parameters (Amaral et al. 2008). Among the conventional biomarkers of radiation exposure, clinical signs and symptoms of acute radiation syndrome, such as nausea, vomiting and diarrhea common during prodromal phase, followed or not by the Hematological, Gastrointestinal and Central Nervous System Syndromes, could predict a range 
of absorbed dose to which the person has been exposed to (Heslet et al 2012). However, it should be kept in mind that the range is generally too wide for estimating the real absorbed dose, serving only for screening the more highly-exposed subjects who require urgent medical intervention. In addition, some laboratorial tests can be performed, such as the leucogram and the counting of platelets. The depletion of these cells from the peripheral blood is commonly related to the severe, moderate and tolerant level of irradiation. For a faster screening, micronuclei assay have been proposed, but this is also not specific to radiation and can be caused by chemical agents (Voisin 1997, Voisin et al. 2001, 2002, Luzhna et al. 2013.). It is worth emphasizing that the identification of persons exposed to absorbed doses higher than 1 Gy would help the medical team in therapeutical planning in order to avoid the symptoms of acute radiation syndrome (Mettler 2012). For doses less than $1 \mathrm{~Gy}$, the health staff would be able to advise the irradiated persons about the risks of stochastic and long term effects.

The gamma-H2AX expression has also been proposed as a biomarker of individual exposure to ionizing radiation. However, this histone subunit undergoes very quick modifications as an immediate radiation response. Then, the lapse of time after an individual exposure is a limiting factor for applying this method in cases of radiation emergencies, unless the blood samples could be sent to analysis within the first hours after irradiation (Sak and Stuschke 2010, Moroni et al. 2013).

The importance of the $\mathrm{p} 53$ protein, as a guardian of genome integrity is due to its role in regulating biological processes such as DNA repair, cell cycle arrest and apoptosis (Vousden and Lane 2007, Liu et al. 2014). Those cellular mechanisms are directly related to the cell response to the in vitro or in vivo physico-chemical stresses. Thus, knowledge about how the expression levels of this protein correlate with the absorbed dose would successfully introduce a new biomarker of individual exposure to ionizing radiation (Cavalcanti et al. 2008, Fei and El-Deiry 2003).

Blood-based assays with stimulated cells, mainly lymphocytes, have been used in the most advanced investigations concerning protein expressions under radioactive stress. As human lymphocytes are well distributed in the human body, staying typically in resting phase (G0), they can reenter the cell cycle if appropriately stimulated to mitosis, maintaining therefore the memory of damage until the cell culture (Lloyd and Dolphin 1977, De Freitas e Silva et al. 2014).

In this context, the measure of p53 protein expression by Flow Cytometry would be a rapid screening method in order to spot those who were actually exposed to ionizing radiation. Once the exposed person has been identified, a more reliable method for estimating the absorbed dose would be the gold-standard dicentric assay (IAEA 2011).

Regarding Figure 1, Group I presents the mean of p53 protein expression levels for 8 subjects. For this group, it is possible to verify a statistically significant difference between the control ( 0 Gy) and the absorbed dose of 4 Gy.

Group II presents the results for expression of p53 protein of another 13 subjects. For this group, statistically significant differences of $\mathrm{p} 53$ protein expression levels were observed among control (0 Gy), 2 and 4 Gy.

The dose-response shown in Figure 1, concerning groups I and II, followed the so-called "linear-quadratic" model, with a similar behavior as that of radioinduced dicentric chromosomes. The shape of this model curve is a result of DSBs of the DNA molecule. This can be explained taking into account that, for lower doses, each DSB is considered to be caused by a single track (interaction) of ionizing radiation, giving the linear shape of the dose response. As dose increases, much more ionizing tracks cross the cell so that the likelihood of DNA damage is much greater 
presenting a quadratic response (Lemos-Pinto et al. 2010, IAEA 2011). In the present study, the same pattern of dose response was observed for p53 protein expression, reinforcing the idea that there is a close relationship between increase of radioinduced DNA damage and the increase of the this protein expression levels.

Comparing each p53 protein expression level of Group I with the respective result of Group II, for each condition (control, 0.5 to $4 \mathrm{~Gy}$ ), significant differences $(p<0.05)$ were observed.

The results pertaining to the subjects $\mathbf{S 1}$ and $\mathbf{S 2}$ are summarized in Table II, and show considerably higher p53 protein expressions than any other individual belonging to the previous groups. Thus, for $\mathbf{S 1}$ and $\mathbf{S 2}$ subjects, one can expect overreactions in terms of cell death and mitotic delay, in comparison to the others.

In radiotherapy, the capacity of predicting the individual radiosensitivity would significantly improve the treatment of cancer (Barnett et al. 2009, Prasanna et al. 2014). Although cellular radiosensitivity is directly correlated with the mechanisms of DNA repair, this parameter in normal tissues is not investigated prior to treatment. Generally, depending on the treatment approach, the dose delivered to the tumor is 2 Gy a day fractions, with a smaller dose to the surrounding tissue. This is responsible for the side effects associated with damages to normal tissues (Hall and Giaccia 2006).

Our preliminary results suggest that the definition of a "normality interval" for $\mathrm{p} 53$ protein expression levels may provide a patient-specific protocol. This would be very important so that radiation sensitive patients could be identified before they undergo therapy. Obviously, further studies with a greater number of subjects are needed to support this hypothesis.

On the other hand, in terms of radioprotection management, the identification of individual less sensitive to radiation would be of great interest for those who need to be occupationally exposed, such as professionals in Nuclear Power Plants, Hospitals, Industries, Research, Aircraft Pilots or Astronauts, in the goal of avoiding or mitigating the risks associated to the exposure to ionizing radiation (Byrne et al. 2014).

\section{CONCLUSIONS}

The response of $\mathrm{p} 53$ protein expression induced by ionizing radiation presents a dose-dependent pattern correspondent to the amount of DNA breaks induced per unit dose. This could be reinforced by the evidence that for some samples the dose-effect follows the linear-quadratic model. Nevertheless, one mind considerer the radiation sensitivity, because for some subjects the dose response follows no patterns, due to the high p53 levels even for lower doses. Thus, even though further studies are needed, the use of the methodology presented in this research would be helpful in the assessment of individual sensitivity to ionizing radiation. Considering the rapidity of flow-cytometric analyses, this work also opens the possibility of applying this methodology in a fast screening of a large number of people suspected of having received an overdose of radiation in the case of accidents or radiotherapy, but also for occupational personnel working on nuclear plants or jet pilots, who are systematically exposed to chronic low radiation doses.

\section{ACKNOWLEDGMENTS}

The authors would like to thank the Centro de Pesquisas Aggeu Magalhães (Fiocruz-CPqAMBrazil) for providing laboratory facilities, and Conselho Nacional de Desenvolvimento Científico e Tecnológico (CNPq-Brazil), for financial support.

\section{RESUMO}

O objetivo deste trabalho foi avaliar a relação entre os níveis da proteína p53 e as doses absorvidas a partir de linfócitos humanos irradiados in vitro. Para isto, amostras 
de sangue de 23 doadores foram irradiadas com 0,$5 ; 1$; 2; e 4 Gy a partir de uma fonte de cobalto-60, e as porcentagens de linfócitos expressando p53 foram quantificadas por Citometria de Fluxo. Os indivíduos foram divididos em três grupos, de acordo com os níveis da p53 expressos por dose de radiação: baixo (Grupo I), elevado (Grupo II), e níveis excessivos (Grupo III). Para todos os grupos, as análises mostraram que os níveis de expressão da p53 aumentam com a dose absorvida. Particularmente para os grupos I e II, a correlação entre a expressão desta proteína e a dose segue o modelo linear-quadrático, como para as aberrações cromossômicas radioinduzidas. Em conclusão, nossos achados indicam possíveis aplicações desta metodologia na avaliação radiossensibilidade individual antes de procedimentos radioterapêuticos, bem como na monitoração médica de trabalhadores ocupacionalmente expostos. Além disso, devido à rapidez das análises por Citometria de Fluxo, a metodologia aqui empregada poderá desempenhar um papel importante nas ações emergenciais em incidentes radioativos de larga escala, onde muitas pessoas podem ter sido expostas.

Palavras-chaves: Dosimetria Biológica, radiobiologia celular, Citometria de Fluxo, proteína p53, radiossensibilidade.

\section{REFERENCES}

Amaral A, Fernandes TS AND CaVAlcanti MB. 2008. Bioindicators in radiation protection. Braz Arch Biol Technol 51: 91-96.

Barnett GC, West M, Dunning AM, Elliott RM, Coles CE, Pharoah PD AND BuRnet NG. 2009. Normal tissue reactions to radiotherapy: towards tailoring treatment dose by genotype. Nat Rev Cancer 9: 134-142.

BYRNE RT ET AL. 2014. Evolution of extreme resistance to ionizing radiation via genetic adaptation of DNA repair. eLife 3: 1-18.

CAVAlCANTI MB, Amaral A, Fernandes TS, Melo JA AND MACHADO CGF. 2008. p53 protein expression levels as bioindicator of individual exposure to ionizing radiation by flow cytometry. Mol Cell Biochem 308: 127-131.

CAVAlCANTI MB, Silva APG, SiLVA RF AND Amaral A. 2011. p53 protein expression and cell viability in irradiated peripheral blood mononuclear cells as bioindicators of radiosensitivity. J Biophys Chem 2: 63-67.
Chen Y, ZHOU PK, ZHANG XQ, WANG ZD, WANG Y AND DARROUDI F. 2014. Cytogenetic studies for a group of people living in Japan 1 year after the Fukushima nuclear accident. Radiat Prot Dosimetry 159: 20-25.

De Freitas e Silva R, Dos Santos NFG, Pereira V and AmARAL A. 2014. Simultaneous analysis of p53 protein expression and cell proliferation in irradiated human lymphocytes by flow cytometry. Dose Response 12: 110-120.

FEI P AND EL-DEIRY WS. 2003. P53 and radiation responses. Oncogene 22: 5774-5783.

Fernandes TS, Lloyd DC AND Amaral A. 2008. A comparison of different cytological stains for biological dosimetry. Int J Radiat Biol 84: 703-711.

GUIPAUD O AND BENDERITTE M. 2009. Protein biomarkers for radiation exposure: towards a proteomic approach as a new investigation tool. Ann Inst Super Sanitá 45: 278-286.

HALl EJ AND GIACCIA AJ. 2006. Radiosensitivity and cell age in the mitotic cycle. In: Hall EJ and Giaccia AJ (Eds), Radiobiology for the radiologist, $6^{\text {th }}$ ed., Philadelphia: Lippincott Williams \&Wilkins, p 47-59.

Heslet L, BAy C AND NePper-Christensen S. 2012. Acute radiation syndrome (ARS) - treatment of the reduced host defense. Int J Gen Med 5: 105-115.

IAEA - INTERNATIONAL ATOMIC ENERGy AGENCY. 2011. Cytogenetic dosimetry: applications in preparedness for and response to radiation emergencies. Vienna: Scientific and Technical.

LeE JK, Han EA, LeE SS, Ha WH, Barquinero JF, LeE HR AND CHO MS. 2012. Cytogenetic biodosimetry for Fukushima travelers after the nuclear power plant accident: no evidence of enhanced yield of dicentrics. J Radiat Res 53: 876-881.

LEMOS-PINTO MM, SANTOS NF AND AMARAL A. 2010. Current status of biodosimetry based on standard cytogenetic methods. Radiat Environ Biophys 49: 567-581.

LiU B, BHATt D, OLTVAI1 ZN, GREENBERGER JS AND BAHAR I. 2014. Significance of $\mathrm{p} 53$ dynamics in regulating apoptosis in response to ionizing radiation, and polypharmacological strategies. Scientific Reports 4: 6245.

LlOYD DC AND DOLPHIN GW. 1977. Radiation-induced chromosome damage in human lymphocytes. Br J Ind Med 34: 261-273.

LUZHNA L, KATHIRIA P AND KovALCHUK O. 2013. Micronuclei in genotoxicity assessment: from genetics to epigenetics and beyond. Front Genet 4: 131.

MetTLer FA. 2012. Medical effects and risks of exposure to ionizing radiation. J Radiol Prot 32: 9-13.

Moroni M, Maeda D, Whitnall MH, Bonner WM AND REDON CE. 2013. Evaluation of the Gamma-H2AX Assay for Radiation Biodosimetry in a Swine Model. Int J Mol Sci 14: 14119-14135.

OLIVE PL. 1998. The role of DNA single- and double-strand breaks in cell killing by ionizing radiation. Radiat Res 150: S42-51.

ORIENT JM. 2014. Fukushima and reflections on radiation as a terror weapon. J Am Phys Surg 19: 48-55. 
Pojogam, Manaila E, CONSTANTIN N, DUTA CG, CimPONERIU D AND SIMON-GRUITA A. 2013. Chromosome aberrations, telomere and telomerase dysfunction after beta irradiation in human lymphocytes. Rom Biotech Lett 18: 8603-8612.

Prasanna PGS, Ahmed MM, Stone HB, Vikram B, Meata MP AND COLEMAN CN. 2014. Radition-induced brasin damage, impact of Michael Robbins'work and the need for predictive biomarkers. Int J Radiat Biol 90: 742-752.

RASHI-ELKELES S ET AL. 2014. Parallel profiling of the transcriptome, cistrome, and epigenome in the cellular response to ionizing radiation. Sci Signal 7(325): rs3.

REDON CE, DICKEY JS, BONNER WM AND SEDELNIKOVA OA. 2009. $\gamma$-H2AX as a biomarker of DNA damage induced by ionizing radiation in human peripheral blood lymphocytes and artificial skin. Adv Space Res 43: 1171-1178.

Riley T, SONTAg E, Chen P AND LEVINE A. 2008 Transcriptional control of human p53-regulated genes. Nat Rev Mol cell Biol 9: 402-412.

ROTHKAMM K AND HORN S. 2009. $\gamma$-H2AX as protein biomarker for radiation exposure. Ann Ist Super Sanita 45: 265-271.
SAK A AND STUSChKE M. 2010. Use of $\gamma \mathrm{H} 2 \mathrm{AX}$ and other biomarkers of double-strand breaks during radiotherapy. Seimin Radiat Oncol 20: 223-231.

SPEIDEL D. 2010. Transcription-independent p53 apoptosis: an alternative route to death. Trends Cell Biol 20: 14-24.

SWEIGERT SE, EGUCHI-KASAI K, WARTERS RL AND DETHLEFSEN LA. 1989. Repair of DNA single- and doublestrand breaks in proliferating and quiescent murine tumor cells. Int J Radiat Biol 56: 253-264.

VOISIN P. 1997. Chromosome lesions as short and medium term biological indictor of acute irradiation. In: Court L and Lallemand A (Eds), l'Homme Blessé. Edf, Paris, p. 139-150.

VOISIN P ET AL. 2002. Towards a standardization of biological dosimetry by cytogenetics. Cell Mol Biol 48: 501-504.

Voisin P, Benderitter M, Claraz M, Chambrette V, SOROKINE-DURM I, DELBOS M, DURAND V, LEROY A AND PAILlOLE N. 2001. The cytogenetic dosimetry of recent accidental overexposure. Cell Mol Biol 47: 557-564.

VOUSDEN KH AND LANE DP. 2007. p53 in health and disease. Nat Rev Mol Cell Biol 8: 275-283. 